\title{
蒸熱による茶葉の物理的性質の変化
}

\author{
上辻久利 ${ }^{*} \cdot$ 堀内久弥** ${ }^{*}$ 西成勝好**
}

\section{Changes in Physical Properties of Tea Leaves by Steaming}

\author{
Hisatoshi KamitsujI*, Hisaya HorIUCHI** \\ and Katsuyoshi NiSHINARI** \\ * Kyoto Prefectural Tea Research Institute, Shirakawa Nakanosono 1, Uji-shi, Kyoto, 611 \\ ** National Food Research Institute, Ministry of Agriculture, Forestry \\ and Fisheries, Yatabe-machi, Tsukuba-gun, Ibaraki, 305
}

\begin{abstract}
The mechanical properties and electric impedance of tea leaves were measured for various steaming durations in order to obtain the basic informations for the automation of steaming process in the manufacture of tea. Dynamic elastic modulus at $10 \mathrm{~Hz}$ and the initial apparent elasticity in extension measurement decreased remarkably with increasing the steaming duration. The breaking strain increased by $40 \%$ caused by steaming only for a short time $(30 \mathrm{~s})$ with comparison to raw leaves. Steamed leaves elongated at initial stage of extension, while raw leaves stretched only a little until just before the breaking. Both the magnitude and the frequency dependence of electric impedance were more eminent for raw leaves than steamed leaves. The large air chambers of intercellular spaces in spongy parenchyma of raw leaves were observed but shrinked rapidly by steaming. The differences of physical properties between the leaves of various positions on the stem were also examined: larger firmness, higher electric impedance and lower moisture content were found at the lower positions on the stem than at the upper positions for the raw leaves.

(Received Jul. 6, 1984)
\end{abstract}

緑茶の製造過程注摘採した生葉を蒸熱し，数段階の抹 ねん・乾燥工程を経て荒茶とするのが一般的である。最 初の蒸熱工程恬短時間であるが, 醉素を失活させ, 緑色 の保存ととむに，葉を柔らげて採み易くする作用があ り，その良否が緑茶品質に与える影響は大きい。ところ が, 茶葉に対する蒸熱勃果を数量的に判定する方法がな いため, 蒸熱した葉の色, 香り, 温度, 表面に出た粘り などの感覚評価に基づいて蒸熱㙨の操作を行っているの が現状である。しかし，製造現場では就練者の不足や， 工程の自動化を促進する面からも，蒸熱の客観的評価と 工程の制御が望まれている。

生葉および蒸熱した茶葉の物理的性質については，色 差計による測色”，果実硬度計あるいは針の貫入による かたさの測定 ${ }^{31}$ ，蒸熱した葉の引㖘り特性 ${ }^{3)}$, 電気抵抗 の測定いなど数件の報告がある。ここでは背果物に用い られている引張り破断特性值, およびフィルム状試料に
ついて測定されている伸縮による動的粘弾性，そして細 胞組織の健全性の目安とされている交流インピーダン ス, 水分含量, 組織構造などが, 蒸熱によってどのよう に变化するものか，測定した結果を報告する。

\section{試料およひ実験方法}

\section{1. 試料}

供試した茶葉（品種：やぶきた）は主として，二番茶 期以降の 1983 年 6 月 16 日， 28 日と 8 月 22 日に茨城県 谷田部町かすみ茶園において採取した。生葉はやや硬化 し，不揃いであったため，葉位別と茎の測定では芽長と 葉数を, 蒸熱時の変化では第 3 位葉で葉長と葉幅を捅え て使用した。茥は第 2 茎のみを用いた。

\section{2. 蒸熱方法}

䅉熱処理は茎からはずした葉㨅，葉脈を含んだ生葉を 小さな金網かでに入れ，沸とうしている電気炊飯器の蒸

* 京都府立茶業研究所（广 611 京都府宇治市白川中／蔆 1 番地）

**農林水産省食品総合研究所（ $\overline{\mathrm{T}} 305$ 荻城県筑波郡谷田部町観音台 2-1-2) 


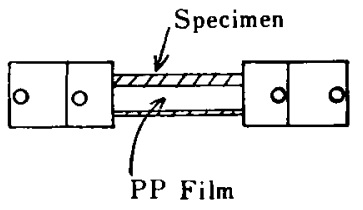

(a)

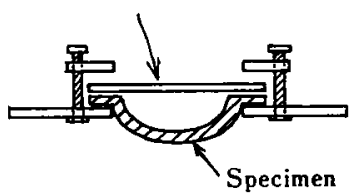

b)

Fig. 1 A clip for dynamic viscoelastic measurement
(a) top view
(b) side view

気に短時間当てた。蒸熱後は直ちに水中に入れて冷却 し，水分の蒸発を防止した。

動的粘弾性測定用試料については, 中心部の葉脈を避 けて幅 $5 \mathrm{~mm}$, 長さ $3 \mathrm{~cm}$ の短册形に切取り, Fig. 1 に 示した補助固定器具に補強用のポリプロピレンフィルム と,たるませた試料を重ねて締付け，器具ごと蒸熱した。

\section{3. 測定方法}

(1) 伸簿振動による動的粘弾性

上記の試料を補助固定器具ごと東洋精機製作所製ビェ ソトロンーU の試料クランプに取付けた後, ポリプロピ レンフィルムを細いハンダゴテで焼切り, 試料を伸ばし て $10 \mathrm{~Hz}$ の正弦振動における動的粘弾性を測定した。 温度制御は行わなかったが, 試料室内の温度は室温と同 し $27^{\circ} \mathrm{C} て ゙$, 変動は $\pm 1^{\circ} \mathrm{C}$ 以下であった。葉面からの水 分蒸散を最小限に抑えるために，周波数依存性は測定し なかった。

測定法の概略は次の通りである。加振器により試料の 一端に加えられた正弦的ひずみを，他端のロードセルで 応力として挨出し, 複素弾性率 $E^{*}$ が得られる。これが 位相検波回路を通って動的弾性率 $E^{\prime}$ と動的損失 $E^{\prime \prime}$ と して読取られる ${ }^{516) 。}$

(2)引張り破断特性

測定用試料は処理した葉から，Fig. 2 のように中央 部の幅 $5 \mathrm{~mm}$ の JIS 準拠のダンベル状に切出し，上村 らクがトマト果皮の測定に用いた治具に準じた補助固定 用のチャックで締付けた。測定はインストロン型万能引 張り王縮試験機（新興通信工業製 TOM-500）を用い, 変形速度 $10 \mathrm{~mm} / \mathrm{min}$ で破断するまで伸張した。変位を 20 倍に拡大して XYレコーダーに自記させた 破断曲線 から，ピークを示す破断応力 $(F / S, S$ 一試料断面積), 破断ひずみ $(D / l, l$ 一試料の長さ), 变位 $D$ までの曲線

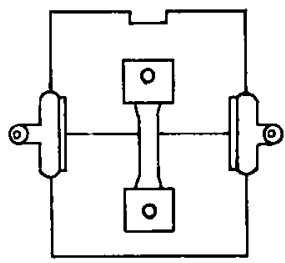

(a)

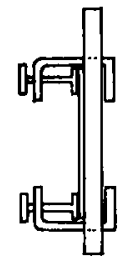

(b)

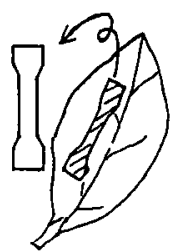

(c)
Fig. 2 A clip for extension measurement

(a) top view, (b) side view, (c) a dumbbell shaped specimen cut from a tea leaf

の囲む面積から破断エネルギー $(A / S)$ ，そして初期の 直線的増加率から見分けの弾性率 $\left(E_{\mathrm{app}}=l \Delta F / S \Delta D\right)$ な どを算出した。

(3) 交流インピーダンス

ヘクトルインピーダンスメーター（横河・ヒューレッ ト・ヘッカード製 $4800 \mathrm{~A}$ ) を用いて，100 Hz から 500 $\mathrm{KHz}$ に括けるインビーダンスの維対值 $|Z|$ を测定した。 測定試料は動的粘弾性と同様に，幅 $5 \mathrm{~mm}$, 長さ $3 \mathrm{~cm}$ に切出し, $1 \times 1 \mathrm{~cm}$ の真ちゅう板を電極としたワニロク リップで㣣えだ。周波数を 15 段階に変えた時の $|Z|$ の 変化を XYレコーダーに記録した。

(4) 水分含量

蒸熱した試料性表面の水滴を拭取って大型フルミニウ 么称量缶に $2 \mathrm{~g}$ を取り，常圧 $135^{\circ} \mathrm{C}$ で恒量になるまで 測定した。また，フルミフォイルの袋に $10 \mathrm{~g}$ を取り， $60^{\circ} \mathrm{C}$ 滅圧乾燥法による測定も合わせて行った。

（5） 細胞組織観察

生葉および蒸熱試料の凍結横断切片について, 50, 100 倍の光学顕微鏡下に, 無染色で観察した。

\section{結果および考察}

\section{1. 生薬の葉位による力学的性質の差異}

動的粘弾性の測定は 10〜20枚の平均值を Fig. 3 に示 した。測定値の变動係数 $(C=s / \bar{x})$ は各葉位を通じて, $E^{\prime}, 22 \sim 37 \%$; 損失正接 $\left(\tan \delta=E^{\prime \prime} / E^{\prime}\right), 16 \sim 25 \%$ で あった。動的弾性率は葉位の大きいものほど大きく，損 失正接は逆に小さくなった。これは上位葉ほど生育が遟 れて，感覚的にも軟らかいことと一致する。各葉位間の $E^{\prime}$ の差はかなり大きく，第 5 葉は第 2 葉のほほ 2 倍で あった。 $E^{\prime}$ の大きさは $10^{8} \mathrm{dyn} / \mathrm{cm}^{2}$ の数值で，他の農 産物, 果実・根菜類の動的弾性率8) とほほ同じオーダー であった。 


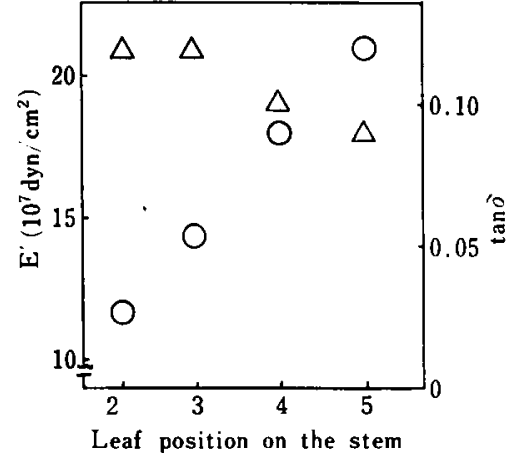

Fig. 3 Dynamic Young's modulus $E^{\prime}(0)$ and mechanical loss tangent $\tan \delta(\Delta)$ of tea leaves at various positions on the stem

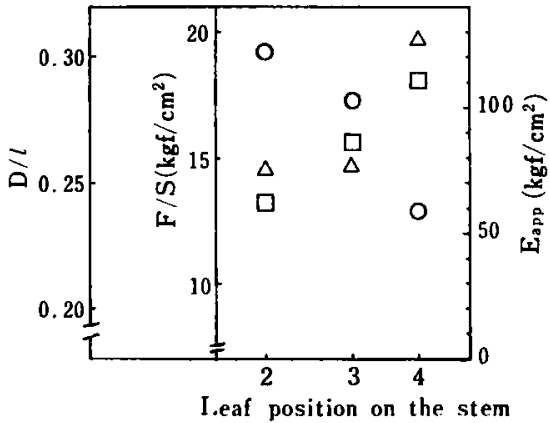

Fig. 4 Breaking strain $D / l(0)$, breaking force $F / S(\square)$ and apparent elasticity $E_{\text {app }}(\Delta)$ of tea leaves at various positions on the stem

引張り破断特性値む10回の平均值を Fig. 4 に示し た。この場合の変動㐿数は $D / l, 12 \sim 26 \% ; F / S, 13 \sim 17$ \%； $E_{\text {app }}, 20 〜 28 \%$ となった。破断ひずみは上位葉ほど 大きく，破断応力は逆に小さくて， $\tan \delta$ と同様に上位 葉が柔らかいことを表わしている。变形初期の見かけの 弾性率は動的弾性葍，破断応力と同しく下位菜の方が大 きいが，葉位順には比例せず，第 3 葉と第 4 葉の差が著 しい。なお破断応力, 見かけの弾性率とも，第 3 葉を用

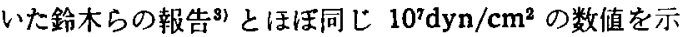
した。

\section{2. 生葉のインピーダンスと水分含量の葉位別変異}

交流インピーダンスの周波数依存性を Fig. 5 に示し た。各葉位別の測定值はそれぞれ 7 枚の試料の平均值で あるが，再現性はかなりよく，各測定周波数ごとに計算 した変動係数は，2葉 2.5〜9\%；3菜 3.1〜11.7\%；

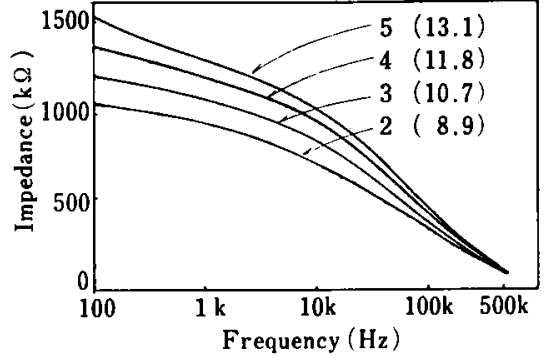

Fig. 5 Frequency dependences of electric impedance for tea leaves at various positions on the stem

Figures beside the curves represent the leaf positions on the stem and the ratio $Z_{100 \mathrm{~Hz}} /$ $Z_{500 \mathrm{KHz}}$

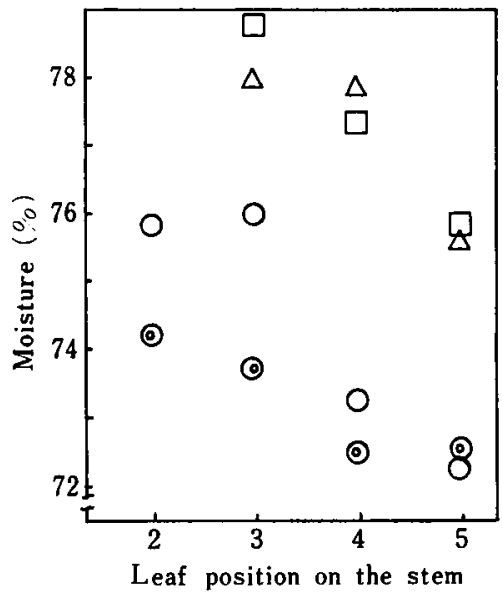

Fig. 6 Moisture contents of tea leaves at various positions on the stem

Marks show the collected date 口-June 18, $\Delta$-June 20, O-June 30 , ๑-Aug. 24

4 葉 2.6〜12.8\%；5葉 3.7〜18.4\% であった。周波 数が低いものは，やはり变動が大きい。周波数が高くな るに従って急激に低下している。100 Hz から $100 \mathrm{KHz}$ にかけては下位菜ほど大きく，500 KHzでは荣位による 差異は見られなかったが， $100 \mathrm{~Hz}$ と $500 \mathrm{KHz}$ とのイン ピーダンスの比 $\left(Z_{100 \mathrm{~Hz}} / Z_{500 \mathrm{KHz}}\right)^{9)}$ をとると，図中に示 したように下位葉ほど大きく，周波数依存性が著しい。 これは後記のように，下位葉ほど水分含量が低いことと， 生育に伴って細胞組織が発達し, 細胞壁の肥厚之細胞間 の空隙の増大に基づくものと考えられる。 
各葉位の含有水分は Fig. 6 亿示したが，一見して数 值のばらつきが大きい。これは図中の各印をたどってみ ると，試料操取日ごとに大きく変動ていることが分かる が，この原因については今のところ理由は不明である。 この変動がないものとみなすと, 葉仙順に下位葉ほど水 分量が少ないということができる。

\section{3. 蒸熱による茶葉の力学的性質の変化}

複素弾性率の蒸熱による変化について 12 14 回の平 均値を Fig. 7 に示した。各処理を通した測定値の変動 俰数は， $E^{\prime}, 16 \sim 45 \% ; \tan \delta, 9 \sim 28 \%$ で，蒸熱葉の変動 はやや大きい。 $E^{\prime}$ および図には示していないが， $E^{\prime \prime}$ は 短時間の蒸熱によって半減した。そして蒸熱時間を延ば すと，さらに徐々に低下した。これに対して $\tan \boldsymbol{\partial}$ 㹥蒸 熱によって増加し，蒸熱時間にかかからず，ほぼ一定值

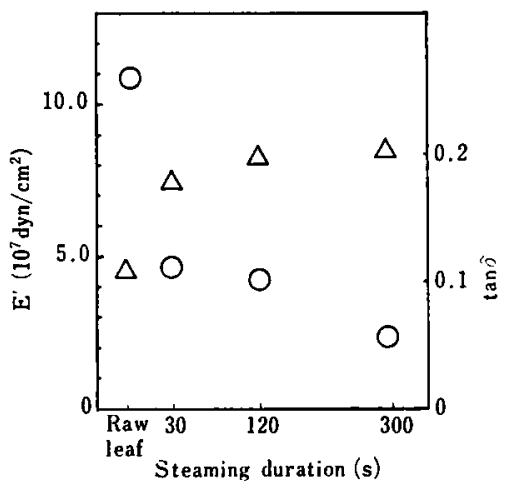

Fig. 7 Dynamic Young's modulus $E^{\prime}(0)$ and mechanical loss tangent $\tan \delta(\Delta)$ of tea leaves for various steaming durations

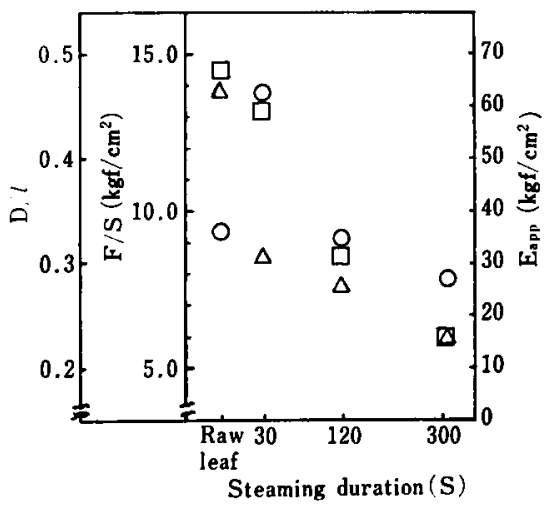

Fig. 8 Breaking strain $D / l(O)$, breaking force $F / S(\square)$ and apparent elasticity $E_{\text {app }}(\Delta)$, of tea leaves for various steaming durations

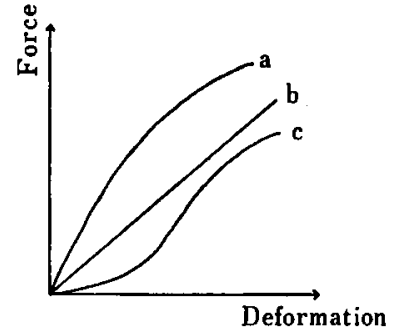

Fig. 9 Typical force-deformation curves for tea leaves

(a) raw leaf, (b) leaf steamed for 30 and

$120 \mathrm{~s}$, (c) leaf steamed for $300 \mathrm{~s}$

を示するのとみなされる。動的特性值には生葉と蒸熱好

理との差が明白に表われるものと考えられる。

引張り破断試験の結果は 7 回の平均值であるが, Fig. 8 に見られるように，見かけの弾性率 $(C=21 \sim 53 \%)$ は 蒸熱により急激に低下し，蒸熱時間に伴ってさらに低下 している。この挙動は鈴木らの報告》とよく似たもの で,さらに，その变化の傾向は前記の $E^{\prime}$ の挙動之も非 常によく一致しており，またオーダーも測定時間領域に よる变化を考虑に入れれば，極めて近い数值と考えら れ，引張り，動的測定とも正確に測定されたものといえ よう。

また破断ひずみ $(C=18 \sim 28 \%)$ は蒸熱 30 秒区で一㭙 的に生葉より $40 \%$ も増加し，それ以後は蒸熱時間が長 くなるに従って生葉より小さな数值を示した。これは非 常に特徽的な現象であるが，鈴木ら" む同様の事例を報 告している。一方, 破断応力 $(C=10 \sim 48 \%)$ 浾熱時 間に従って急激に小さくなっているが，30秒区ではあ まり低下していない。これは前記のように伸びひずみが 大きいために破断が遅れ，大きな破断強度を示すに至っ たものと考えられる。さらにもう一つの特性值である破 断エネルギーは，図示していないが破断ひずみと同じ傾 向完示した。

蒸熱処理による 変形-応力曲線は Fig. 9 のように変 化した。すなわち，生葉は金属の引張り試験のように， 上方に凸形の曲線を示し，破断前に応力集中が起り，部 分的に伸長が始まって破断に至ることを表わしている。 30 秒および 120 秒蒸熱区では变形量に比例して応力が 増加し, 突然, 破断する。300秒蒸熱したものは引張り 初期に容易に伸張し，柔軟ゴムのように下方に时曲した 曲線10)を示した。

4. 蒸熱による苯蕉のインピーダンスの低下

Fig. 10 に交流インピーダンスの周波数依存性を示し 


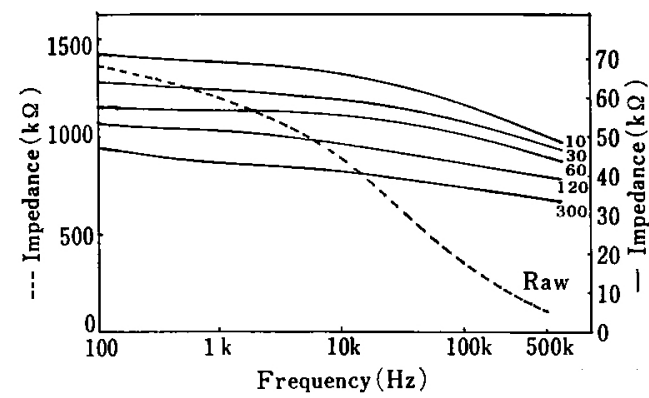

Fig. 10 Frequency dependences of electric im pedance of tea leaves for various steam. ing durations

Figures beside the curves represent steaming duration(s)

た。これらは葉位別の 実験と同㥞に 5 回の実験の平均 值であるが，各周波数ごとの変動係数は 生葉で 4.5 14.3\%であった。蒸熱したものは意外に再現性がよく， 5.1〜12.6\% であった。300秒蒸熱したものは，16.5〜 18. 3\% とやや変動が大きかった。生葉の周波数依存性 が大きいことは Fig. 5 でも示したが，植物組織は抵抗 とコンデンサーの電気回路で表わすことができ，健全な 細胞膜はコンデンサーの働きをすると考光られている11 〜14。一般にコンデンサーのインピーダンスは低周波で 大きく，高周波になるほど小さくなる ${ }^{15)}$ 。従って，健全 な植物組織におけるインピーダンスの周波数依存性は容 易にうなずけるものであり，生葉の測定結果はこの説明 に従うものと考えられる。

しかし，蒸熱した茶葉ではいずれも生葉の約 $1 / 20(100$ $\mathrm{Hz}$ ）減少し，周波数依存性も生葉よりはるかに小さ くほほえぞフラットである。そして烝熱時間が増すと インピーダンスはさらに低下する。つまり, 蒸熱によっ て細胞は生命を失い,インタクトな状態での細胞膜のコ ンデンサーとしての機能は低下し，インピーダンスの周 波数依存性が小さくなったものと考えられる。

\section{5. 蒸熱による岽葉細胞組織の変化}

一方，複雑な植物組織の電気抵抗は細胞間隙む大きな 要因となる16)のではなかろうかと推察される。そこで， 生葉と蒸熱した葉の横断面を顕微鏡下で比較した。Fig. 11 に見られるように，生葉では表面の柵状細胞に続い て，裹面の気孔につながる海綿状組織が発達し，大きな 空隙の存在が認められるが，この空気層が生葉の大きな インピーダンスの一因ではなかららかと考えられる。ち なみに，この切片で計測すると，生葉の厚さはほほ 0.25 (a)

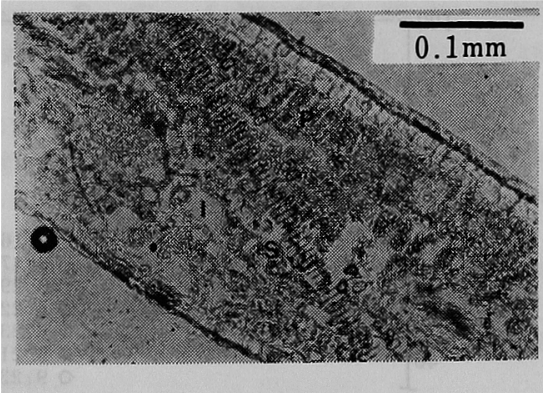

(b)

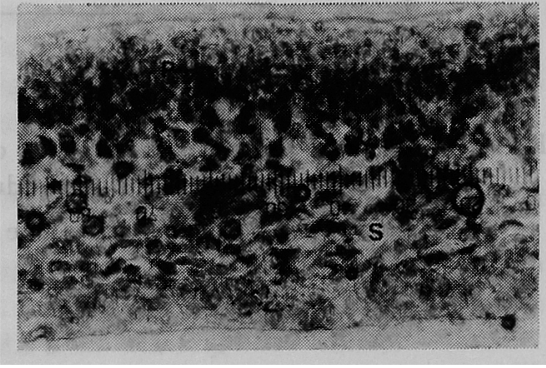

Fig. 11 Microscopic observation of the cross section of tea leaf $(\times 100)$

(a) raw leaf, (b) leaf steamed for $120 \mathrm{~s}$. P-Palisaden parenchyma, S-Spongy parenchyma, I-Intercellular spaces

$\mathrm{mm}$ であった。

これに対して，蒸熱した葉では海綿状組織がほとえど 潰れ，細胞間の空陌が消失していることが観察された。 このような状態では細胞相互の接触が増加して，インピ ーダンスが低下するものと考えられる。

なお，茶葉の蒸熱により細胞内顆粒が凝集するといわ

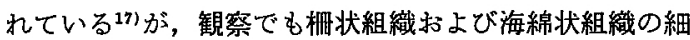
胞内顆粒が中央部に集まっているのが認められた。細胞 内での顆粒の凝集は細胞内圧一膨圧の減少を表わし, 細 胞壁の弾性の低下につながるむのと考えられる。

\section{6. 蒸熱による茶葉水分の变化一軟化要因}

水分の多い青果物のかたさについては，一般的に萎调 による膨圧の低下が 組織の軟化を招く ${ }^{818)}$ とされてお り，試料の表面積が大きいホウレンソウでは，萎调に際 して水分含量と弾性率がほぼ比例関係にあることが認め られている191。これに対して，青果物を加熱した時の軟 化は，細胞壁あるいは細胞間のプロトペクチンの分解ま たは溶解による といわれ，長時間の煮熟では水分合量 が 10\% 内外増加するとされている。茶葉の蒸熱に際し た弾性率の低下，インピーダンスの減少などの物理的性 質の变化が，上記のいずれに基因するものか興味のある 


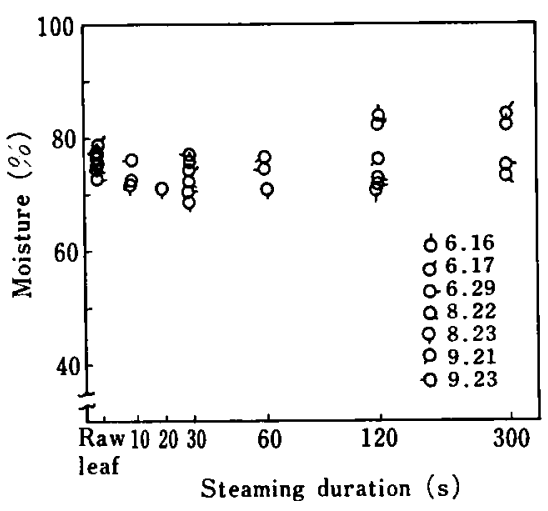

Fig. 12 Relation between the moisture content of tea leaves and the steaming duration

Tea leaves were collected on the date shown in the figure

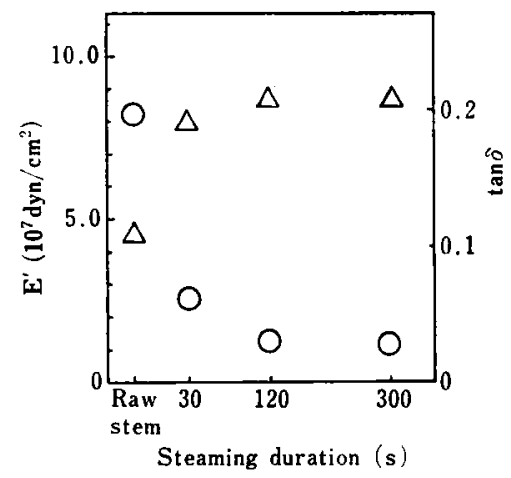

Fig. 13 Dynamic Young's modulus $E^{\prime}(0)$ and mechanical loss tangent $\tan \partial(\Delta)$ of tea stems of various steaming durations

ところである。ここでは化学的成分の変化は測定してい ないので，变化の一面にしか触れることはできないが， 蒸熱時の水分を測定してみると，Fig. 12 に見られるよ うに，測定值のばらつきが非常に大きい。Fig. 6 と同 様に, これも試料採取日による変動と考えて図を見直す と，最終的にはやや增加するものの，短時間の加熱て はむしろ生葉より減少しているるのと考えられた。力学 的性質の急激な変化がこの点に表われたことは興味深い が,この時の弾性率の低下はかなり急激なため, 蒸熱初 期の茶葉の軟化注 Fig. 11 で観察された，細胞内顆粒 の凝集に表われる膨圧の低下に基因する部分が大きいの ではなかろうかと考えられる。しかし他方では蒸熱によ
る化学的成分の变化を研究し, 水溶性ペクチンの増加を 認めた報告 ${ }^{211}$ むあるので，いずれか一方の原因と断定す ることはできないであるう。茶葉の水分含量の変化を精 密に把握することが, これを明らかにする一つの方途で はなからうかと考元られる。

\section{7. 蒸熱による䔄の力学的性質の变化}

茎については動的測定のみを行ったが， $E^{\prime}(C=13 \sim$ $42 \%)$ および $\tan \delta(C=5 \sim 16 \%)$ の挙動は葉の場合と ほとんど同じであった。また $E^{\prime}, \tan \partial の$ 数值も葉とほ とえど変らないことが注目される。一般に茎は堞よりか たいと考えられるが，茶の新らしい茎は木質化が進んで いないためであろう。

なお，茎の水分含量は生のものる，蒸熱した後も $83 \%$ を示した。生葉の平均値， $77 \%$ に比べると約 $6 \%$ む高 いことは興味深いことである。

要䄪

製茶における蒸熱工程の合理化を目的として，蒸熱に よる茶葉の力学的性質, 交流インピーダンス, 水分含 量,および細胞組織などの変化を測定した。

まず，生菜の物理的性質は菜位順代变異していること が認められた。すなわち，下位葉ほどかたく，交流イン ピーダンスが大きく，その周波数依存性む大きい。水分 含量は試料採取日による变動はあるが，下位葉のほうが 少なかった。

蒸熱により $10 \mathrm{~Hz}$ の動的弾性率，および弓張り初斯 の見かけの弾性事とも急激に低下したが，蒸熱時間には あ安り依存しなかった。破断ひずみは蒸熱 30 秒後に生 葉より $40 \%$ る増加し，その後，生葉よりやや小さくな った。破断応力は初めわずかに低下し，蒸熱時間が長く なるに従って减少した。交流インピーダンスは蒸熱によ りその大きさが生葉の $1 / 20$ ぐらいに低下し，周波数估 存性む小さくなった。

茶集の水分含量は蒸熱初期にやや乾燥するように見受 けられたが，供試生葉の数值が変動するために断定しえ ない。生䈎には裏面の気孔につながる海綿状組織の大き な空腙が顕微鏡下に認められるが，蒸熱によりほとんぞ 消滅した。菱の水分注葉より多いが，動的弾性率および 蒸熱によるその变化る葉とほとえど同じであった。

終りに試料をご恵与下さった，谷田部町かすみ茶園倉 持嘉一郎氏行御礼申上げる。

本辄告の概要は本学会第 31 回大会（1984 年 3 月）に おいて発表した。 


\section{文献}

1) 京都府立茶業研究所試験成縝書, 昭和 52 年度 (1977) ～昭和 55 年度 $(1980)$, 各 p. 1 .

$2 ） 三$ 重県農業試験場茶業分場昭和 38 年度業務報告， p. 58 (1963); 柔原穆夫・新合光雄：茶業技術研 究, No. 5, 34 (1951).

3) 鈴木勝弘・滝谷 洋-吉富 均・中野不二截：昭 和 57 年度荣業技術研究発表会嘎演要旨集, p. 91, 金谷 (1983).

4）埼玉県茶業試験場昭和 56 年度製茶に関する試験 成績, p. 50 (1981).

5) 媣田栄一：レオロジー測定法，高分子学会編（共 立出版, 束京), p. 178 (1965).

6) Nishinari, K., Horiuchi, H. and Fukada, E.: Rep. Prog. Polymer Phys. Japan, 23, 759 (1980).

7）上村昭二・吉川宏昭・伊藤喜三男：園試報， C 7, 73 (1972).

8) Haman, D. D. and Diehl, K.C.: Food Tech. 32, 57 (1978).

9) Hayashi, T., Iwamoto, M. and Kawashima, K.: Agric. Biol. Chem., 46, 905 (1982).

10) ジョン・ウルフ編，永宮健夫監訳：材料科学入門 III, 機械的性質 (岩波書店, 東京), p. 1 (1967).
11) Svejda, F.: Can. J. Plant Sci., 46, 441 (1967).

12) Greenham, C. G., Randall, P. J. and Ward, M. M.: J. Exp. Botany, 23, 197 (1972).

13）渡辺 昭：生物物理学满座 9, 膜の生物物理, 生 物物理学会編 (吉岡書店, 京都), p. 75 (1966).

14) de Plater, C. V. and Greenham, C. G.: Plant Physiol., 34, 661 (1959).

15）籍田光一：物理学選書 1，エレクトロニクスの基 整 (裳華房, 東京), p. 91 (1963).

16) Fenson, D.S.: Can. J. Plant Sci., 46, 169 (1966).

17）桑原穆夫・中山 仰：茶業技術研究，No. 3,30 (1950).

18）宮脇長人・矢野俊正：食品の物性 6 , 典産物の力 学物性, 山野普正編 (食品資材研究会, 東京), p. 115 (1980).

19）黑田佐俊・秋元浩一・杉本俊一・川幅保弘：榓機 誌, 39, 199 (1977).

20）堀越フサエ：新調理科学盘座 5, 穀物・野菜の調 理, 下田吉三・松元文子・元山 正・福場博保編 (朝會書店, 東京), p. 150 (1972).

21）高柳博次・阿南豊正・池ヶ谷蜸次郎：昭和 58 年 度茶業技術研究発表会講演要旨集, p. 9, 金谷 (1984).

(昭和 59 年 7 月 6 日受理) 